\title{
Yoğun Bakım Ünitesi Hastaları Kan Külttürlerinden İzole Edilen Candida parapsilosis Suşlarının Mini Epidemiler Bakımından Araştırılması
}

\author{
Efdal OKTAY, Harun GÜLBUDAK, Didem ÖZGÜR, Feza OTAĞ \\ Mersin Üniversitesi Tıp Fakültesi, Tıbbi Mikrobiyoloji Anabilim Dalı
}

\section{ÖZET}

\begin{abstract}
Amaç: Yoğun bakım ünitelerinde yatan hastalarda kateterizasyona bağlı olarak gelişen fungal enfeksiyonlar arasinda en sık kan dolaşımı enfeksiyonları görülmektedir. Candida albicans endojen kaynakl olmasindan dolayı nozokomiyal fungal enfeksiyonlarda ilk sirada yer almaktadır. Antifungal tedaviye daha zor yanit veren Candida tropicalis, Candida parapsilosis, Candida glabrata gibi albicans-dışı Candida türleriyle karsılaşma oranı hızla artmaktadır. Bu çalışmada, nozokomiyal potansiyeli bulunduğu bilinen C. parapsilosis suşlarının klonal yakınlıklartnin rep-PCR (Repetitive Extragenic Palindromic ElementPolimeraz Zincir Reaksiyonu, bioMeriéux, Fransa) DiversiLab ${ }^{\circledR}$ yöntemiyle belirlenmesi amaçlanmıştır.
\end{abstract}

Gereç ve Yöntem: Ocak 2012 ve Haziran 2013 yılları arasinda santral venöz kateterden alınan kan örneklerinden izole edilen 33 C. parapsilosis suşu çalıșmaya dâhil edilmiştir. Klasik yöntemlerle tür tanısı yapılan suşların klonal ilişkileri rep-PCR DiversiLab ${ }^{\circledR}$ sistemi ile belirlenmiştir.

Bulgular: Rep-PCR DiversiLab ${ }^{\circledR}$ sistemi ile yaptlan klonal ilişki analizi sonucunda üç (A-C) farklı klon tespit edilmiş, A klonunun (\%87.8, $n=29)$ baskın tip olduğu belirlenmiştir. $B$ klonuna ait 3 suş, $C$ klonunda ise bir suş saptanmıştır. A klonu, reanimasyon ünitesi örneklerinin \%48.2'sinden, pediyatri yoğun bakım ünitesi örneklerinin \%20.6'sl, cerrahi yoğun bakım ünitesi örneklerinin \%17.2'sinden ve dahiliye yoğun bakım ünitesi örneklerinin \%13.7'sinden izole edilmiştir. İlk ve son suşun izolasyon tarihleri arasında on sekiz ayllk süre olduğu belirlenmiştir.

Sonuç: C. parapsilosis suşlarının servisler arası transfer edilen hastalar ve çapraz bulaşlar sonucu yayıldiğı düşünülmüsştür. Çalışmada kullanılan rep-PCR DiversiLab ${ }^{\circledR}$ sisteminin epidemiyolojik çalısmalarda ve enfeksiyon kontrolünde kullanilabilecek kolay uygulanabilen, hizlı ve başarılı bir yöntem olduğu kanısına varılmıştır. Suşların hastane ortamındaki dă̆llımının klonal ilişki göstermesi, enfeksiyon kontrol önlemlerinin önemini bir kez daha vurgulamaktadır.

Anahtar kelimeler: Candida parapsilosis, Nozokomiyal fungal enfeksiyon, rep-PCR DiversiLab ${ }^{\circledR}$

\section{SUMMARY}

Investigating of Candida parapsilosis Strains Isolated from Blood Cultures of Patients in Intensive Care Unit in Terms of Mini-Epidemics

Objective: Bloodstream infections are seen the most common fungal infections which is caused by catheterization in the hospitalized patients in intensive care units. Candida albicans is the first nosocomial fungal infection owing to endogenous origin. Incidence of non-albicans Candida species (Candida tropicalis, Candida parapsilosis, Candida glabrata) that have antifungal treatment problems, are increasing rapidly. The aim of this study was to determine the clonal relationship between strains of $C$. parapsilosis by using rep-PCR (Repetitive Extragenic Palindromic Element-Polymerase Chain Reaction, bioMeriéux, Fransa) DiversiLab ${ }^{\circledR}$ method.

Materials and Methods: A total of 33 C. parapsilosis strains isolated from blood samples obtained from central venous catheter between January 2010-June 2013 were included in the study. Clonal relationships of Candida parapsilosis strains which were type diagnosed by the conventional methods were determined by rep-PCR DiversiLab ${ }^{\circledR}$ system.

Results: Rep-PCR DiversiLab ${ }^{\circledR}$ analysis have shown the presence of three clones (A-C). Clone A was found to be the dominant type. Twenty nine (87.8\%) of the 33 C.parapsilosis strains belonged to clone A, $3(9.0 \%)$ to clone B, one strains to clone C. Clone A was isolated from $48.2 \%, 20.6 \%, 17.2 \%$, $13.7 \%$ of the samples sent from reanimation unit, pediatric intensive care unit, surgical intensive care unit, internal diseases intensive care units, respectively. Eight month interval has been found between first and last isolations.

Conclusion: As a result; it is contemplated that C. parapsilosis strains were scattered as a result of cross transmission and patient transfer among clinics. The repPCR DiversiLab ${ }^{\circledast}$ system which was used in this study has been evaluated as a rapid, easily applicable and successful procedure for epidemiological studies. Clonal distribution of strains in the hospital environment emphasizes the significance of infection control measures.

Keywords: Nosocomial fungal infection, Candida parapsilosis, rep-PCR DiversiLab ${ }^{\circledR}$

Alındığı tarih: 16.06 .2015

Kabul tarihi: 04.12.2015

Yazışma adresleri: Efdal Oktay, Mersin Üniversitesi Tıp Fakültesi, Tıbbi Mikrobiyoloji Anabilim Dalı, 34. Cadde, Çiftlikköy Kampüsü, Mersin e-posta: efdaloktay@gmail.com 


\section{GíRiş}

Son yıllarda modern tedavi yaklaşımlarının gelişmesi, kemoterapi ve diğer immünsupresif tedavi alan hastaların sayısının artması, transplantasyon cerrahisinin gelişmesi, geniş spektrumlu antibiyotiklerin kullanımı, yoğun bakım ünitesi (YBÜ)'de yatan hasta sayısının artması ve hastalara uygulanan invazif işlemler nedeniyle albicans-dışı Candida (ADC) türlerinin neden olduğu enfeksiyonların sıklığında belirgin bir artış görülmüştür ${ }^{(1-3)}$.

Son epidemiyolojik verilere göre Candida albicans en sık etken olarak kalırken, Candida parapsilosis, Candida glabrata ve Candida tropicalis gibi türlerin prevalansında artış olmasiyla $C$. albicans enfeksiyon insidans1 göreceli olarak azalmıştır ${ }^{(4,5)}$. Türkiye'de C. parapsilosis, C. albicans'tan sonra siklikla kandidemi yapan türdür. $C$. parapsilosis daha çok deri ve mukozadan kaynaklanan kandidemiye yol açmaktadır. Bu tür, kateter ve implantlarda biyofilm oluşturma ve hastane ortamında kalıcılığ 1 yanında bebek ve yenidoğan enfeksiyonlarıyla bilinmektedir ${ }^{(6)}$. Bir ünitede kan kültürlerinde $C$. parapsilosis üremesi enfeksiyon kontrolünün eksikliği yönünden bir gösterge olarak kabul edilmektedir. Yoğun bakım ünitelerinde görülen kan dolaşım sistemi kandidozlarında Candida türleri ya enfeksiyon etkeni ya da kolonizan olarak karşımıza çıkmaktadır $^{(6-8)}$. Yoğun bakım üniteleri gibi riskli hastaların yattığ 1 birimlerde, enfeksiyonların 1/3'inden fazlası çapraz bulaşmayla meydana gelirken; kontrol önlemlerinin yetersizliği hâlinde bu oran daha da yükselmektedir ${ }^{(9)}$. Hastane kaynaklı enfeksiyonlarda yayılımın kontrol edilmesi ve gerekli önlemlerinin alınması için epidemiyolojik çalışmalar önemlidir. Bunun için kolay uygulanabilen, ayrım gücü yükssek moleküler yöntemler tercih edilmelidir. Bu yöntemlerle izole edilen suşların genetik ilişkilerinin varlığ ve bulaş yolları saptanabilmektedir ${ }^{(7,10)}$.

Çalışmamızda, hastanemiz YBÜ hastalarının kan kültürlerinden izole edilen $C$. parapsilosis suşlarının olası mini epidemiler bakımından genetik yakınlıklarının incelenmesi amaçlanmış ve bunun için ticari bir sistem olan yarı-otomatik rep-PCR DiversiLab ${ }^{\circledR}$ (bioMeriéux, Fransa) sistemi kullanılmıştır.

\section{GEREÇ ve YÖNTEM}

\section{Candida Suşlarının Seçimi}

Mersin Üniversitesi Tıp Fakültesi Sağlık Araştırma ve Uygulama Hastanesi'nde Ocak 2012 Haziran 2013 tarihleri arasında yoğun bakım ünitelerinde yatan hastaların santral venöz kateterinden alınan kan (SVK) kültürlerinden izole edilen 33 C. parapsilosis suşu çalışmaya dahil edilmiştir. $C$. parapsilosis' in çalışma suşu olarak belirlenmesi, hastanemizdeki 9 yıllık maya profilinde SVK kültürlerinde en sık izole edilen maya türünün $C$. parapsilosis olmasina dayanmaktadır ${ }^{(11)}$. Bir ünitede aynı zaman diliminde yatan hastalardan izole edilmiş olan $C$. parapsilosis suşları hastane enfeksiyonu etkeni olabileceği düşünülerek seçilmiştir. Hastayı temsil eden tek suşun seçiminde, kültür için gönderilen eşzamanlı her iki şişesinde birden $C$. parapsilosis üremesine ve $\operatorname{ard} 1 s ̧ 1 \mathrm{k}$ en az 3 kan örneğinden izole edilmiş olmasına dikkat edilmiştir.

\section{Suşların Tanımlanması}

Otomatize kan kültür sisteminde (BACTEC) takip edilen ve pozitif sinyal ile sistemden çıkarılan şişelerden hazırlanan Gram preparatlarda maya hücrelerinin görülmesi ile Sabouraud dekstroz agar (SDA) ve kromojenik substratlı (CHROMagar-Candida) besiyerlerine pasajlanarak $37^{\circ} \mathrm{C}$ 'de $24-48$ saat inkübe edilmiştir. SDA besiyerinde üreyen maya kolonilerinin tür tanılarının yapılmasında konvansiyonel yöntemler (Tween-80'li mısır unlu jelozda gerçek/yalanc1 hifler ile klamidospor varlığ 1 , kromojenik agardaki pigmentleri, insan serumunda çimlenme borusu oluşumu) ile ticari kit (API ID $32^{\circ} \mathrm{C}$, bioMeriéux, Fransa) kullanılmıştır ${ }^{(12)}$. Tüm suşlar PCR çalışması yapılıncaya kadar \%10 gliserollü buyyonda $-30^{\circ} \mathrm{C}$ 'de saklanmıştır.

\section{Klonal ilişkilerin araştırılması}

Tüm suşlar, ticari PCR karışımı ve mikro akış- 
kan jel elektroforezi bulunan rep-PCR(Repetitive Extragenic Palindromic Element-Polimeraz Zincir Reaksiyonu) DiversiLab ${ }^{\circledR}$ (bioMeriéux, Fransa) sisteminde çalışılmıştır.

DNA izolasyonu, "UltraClean ${ }^{\mathrm{TM}}$ Microbial DNA Isolation Kit" (MoBio Laboratories, ABD) kullanılarak üretici firma önerileri doğrultusunda yapılmıştır. DNA miktarları nanodrop cihazı ile ölçülerek $35 \mathrm{ng} / \mu \mathrm{l}$ olacak şekilde seyreltilmiştir. DNA amplifikasyonu, Candida DNA parmak izi kiti (DiversiLab ${ }^{\circledR}$, DNA Fingerprinting Kit, bioMeriéux, Fransa) kullanılarak yapılmıştır. Termal döngü parametreleri, başlangıç denatürasyonu $94^{\circ} \mathrm{C}$ 'de 2 $\mathrm{dk}, 35$ döngüdeki denatürasyon $94^{\circ} \mathrm{C}$ 'de 30 $\mathrm{sn}$, primer bağlanmas $150^{\circ} \mathrm{C}^{\prime} \mathrm{de} 30 \mathrm{sn}$, zincir uzamas $170^{\circ} \mathrm{C}$ 'de $90 \mathrm{sn}$. son uzama $70^{\circ} \mathrm{C}$ 'de 3 $\mathrm{dk}$ şeklinde uygulanmıştır. Elektroforez işlemi, DiversiLab ${ }^{\circledR}$ DNA LabChip Kit'i (bioMérieux, Fransa) ile Agilent 2100 bioanalyzer (Agilent Technologies Inc, ABD) cihazında yapılmıştır.

Rep-PCR parmak izi sonuçları internet tabanlı DiversiLab $^{\circledR}$ analiz programı (bioMérieux, Fransa) ile elde edilmiştir. Örneklerin benzerliklerinin belirlenmesi ve dendogram oluşturmak için Pearson korelasyon katsayısı ve UPGMA (aritmetik ortalama kullanarak ağırlıksız gruplama) yöntemi kullanılmıştır. Sonuçların değerlendirilmesinde \%95'in üzerinde benzerlik gösteren suşlar ana klon, ana klon içerisinde \%97'nin üzerinde benzerlik gösteren suşlar alt tip (ayırt edilemez) olarak kabul edilmiştir. Benzerlik oranları \%95'in altında ( $>2$ bant farkı) olan suşlar farklı klon olarak de ğerlendirilmiştir ${ }^{(13)}$.

\section{BULGULAR}

Çalışma kapsamına alınan hastaların 23' ü (\%69.7) erkek, 10'u (\%30.3) kadın, yaş ortalamas1 37.9 (1 ay-87 yıl) ve en sik $C$. parapsilosis izole edilen yaş grubu 0-20 yaş grubu (13 hasta, \%39.3) olarak saptanmıştır. Hastanede yatış süresi ortalama 44 gün (6-156 gün) olarak belirlenmiştir.
C. parapsilosis suşlarının 12 (\%36.3)'si reanimasyon (REA)'da yatan hastalardan, 21 (\%63.6)'i ise diğer servislerden izole edilmiştir. Suşların diğer servislerdeki dağılımı; dahiliye yoğun bakım ünitesi (DYBÜ) 5 (\%15.1), cerrahi yoğun bakım ünitesi (CYBÜ) 5 (\%15.1), pediyatri yoğun bakım ünitesi (PYBÜ) 11 (\%33.4) şeklindedir (Şekil 1).

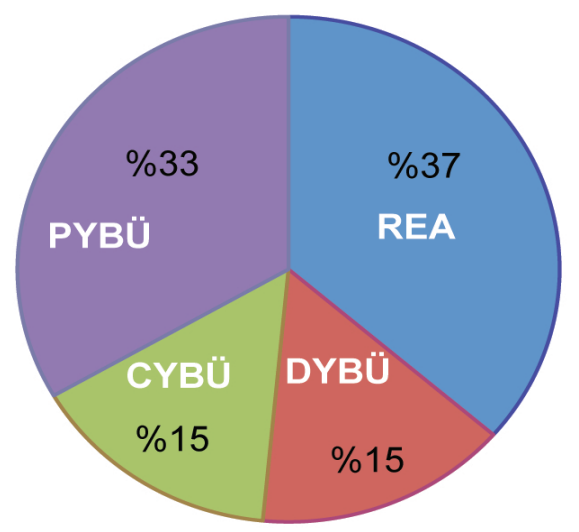

Şekil 1. Candida parapsilosis suşlarının servislere göre dağılım oranı.

Rep-PCR DiversiLab ${ }^{\circledR}$ yöntemi ile 3 farklı klon (A-C) belirlenmiştir. A ana klonu C. parapsilosis'lerin 29 (\%87.8)'unun topland1ğ1 en büyük klon olarak tespit edilmiştir (Şekil 2). B klonunda 3 suş (\%9.1), C klonunda 1 (\%3.1) suş kümelenmiştir. A klonunu oluşturan C.parapsilosis suşu, REA (n: 14), DYB (n: 4), CYB (n: 5), PYB (n: 6)'nde Ocak2012 ve Haziran 2013 tarihleri arasında varlığını sürdürmüştür. B klonunundaki 3 suş, PYBÜ'de Şubat-2012 ile Haziran-2012 tarihleri arasında varlığını sürdürmüştür. C klonundaki tek suş ise Mart-2013 tarihinde PYBÜ'de yatan hastadan izole edilmiştir (Tablo 1).

\section{TARTIŞMA}

Son y1llarda Candida türlerinin neden oldukları enfeksiyonlarda artış olmakla birlikte, bu enfeksiyonlara neden olan türlerin çeşitliliğinde de değişiklikler görülmeye başlanmıştır. Endojen kaynaklı olması nedeniyle, hâlâ nozokomiyal fungal enfeksiyonlarda ilk sirayı $C$. albicans almasına rağmen, antifungal tedaviye daha zor 


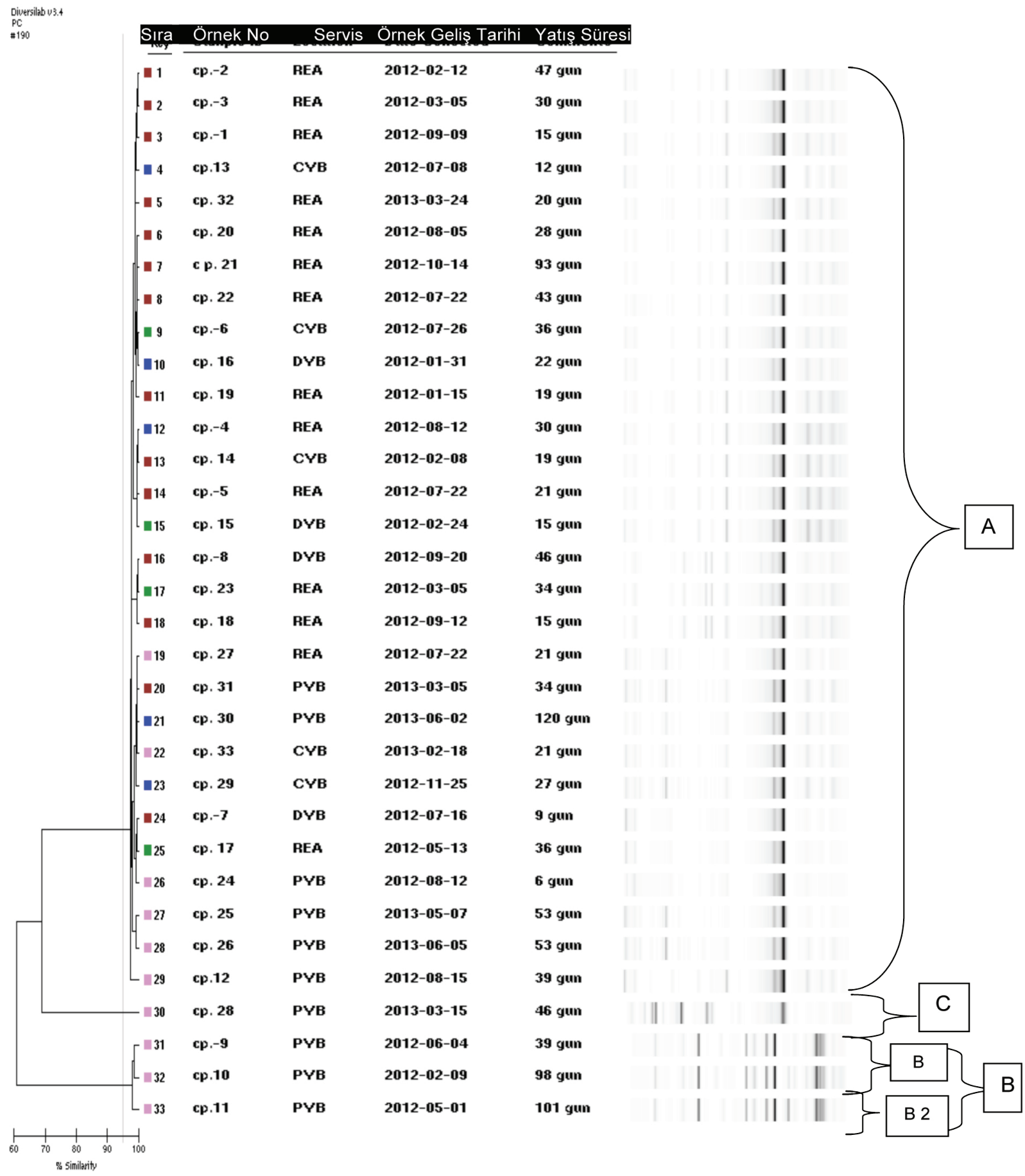

Şekil 2. Rep-PZR analizi sonucunda Candida parapsilosis klonlarma ait dendrogram.

yanıt verdiği bilinen $C$. tropicalis, $C$. parapsilosis, C. glabrata gibi ADC türleriyle karşılaşma oranı hizla $\operatorname{artmaktadir}^{(7,8,10,14)}$.

Ülkemizde ve diğer ülkelerde yapılan çeşitli çalışmalarda YBÜ'de yatan hastaların kan örneklerinden izole edilen maya mantarlarından
C. albicans'1n en s1k saptanan tür olduğu dikkati çekmektedir. ADC türleri içinde en sık saptananlar ise $C$. parapsilosis, $C$. glabrata veya C. tropicalis'tir ${ }^{(6,10,14-18)}$. Candida türlerinin siklık sıralaması, çalışmanın yapıldı ̆̆ 1 hasta grubunun özelliklerine, hastanenin özelliklerine ve coğrafi lokalizasyona göre değişiklik 
Tablo 1. Candida parapsilosis suşlarının aylara ve servislere göre dağılımı, A, B, C: Rep PCR klonları.

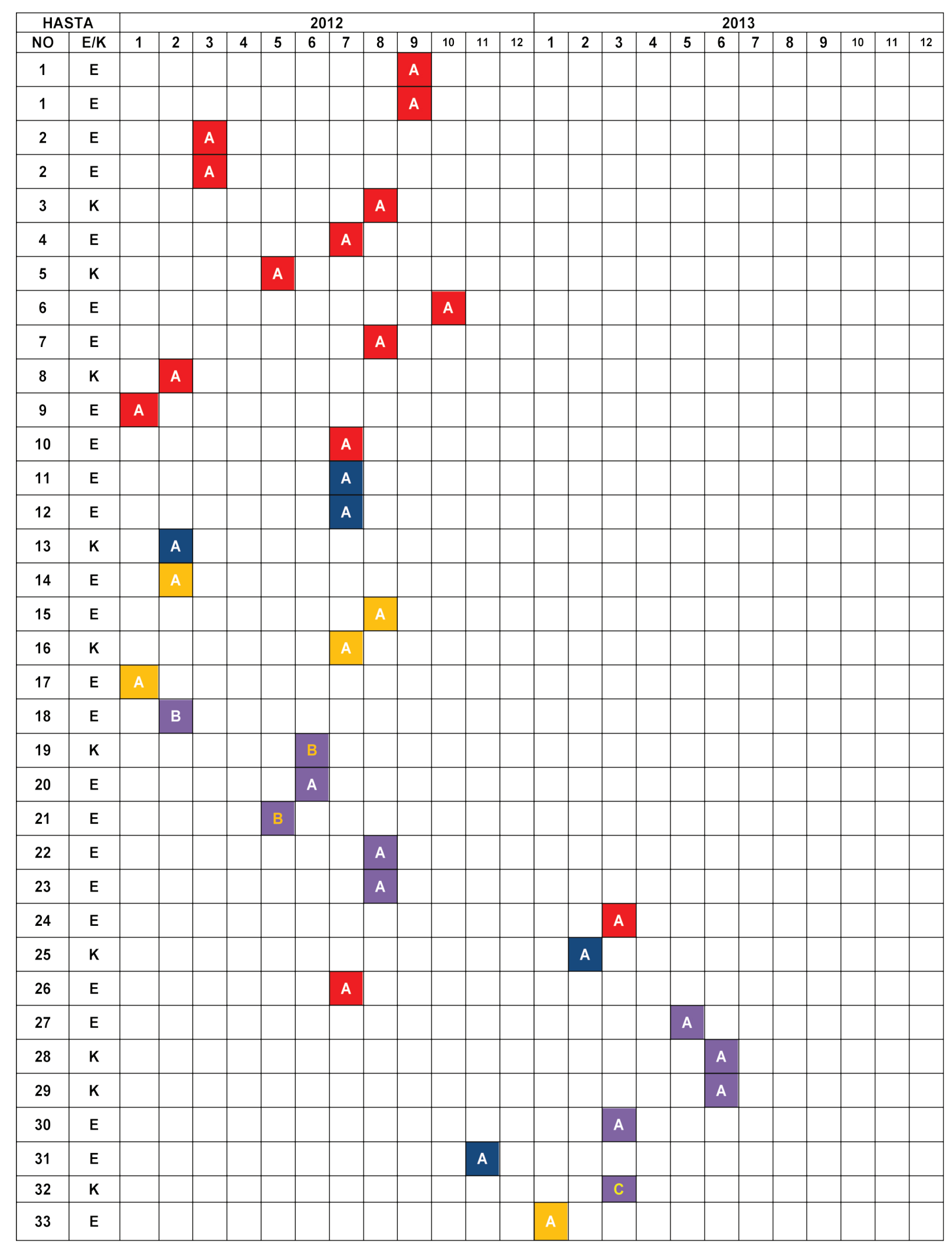


göstermektedir. Birçok çalışmada, kandidemi etkenlerinde belirgin derecede bir değişiklik olduğu ve ADC'lere bağlı kandidemi oranının yaklaşık \%50'lere ulaştığ ${ }^{\prime}$ belirtilmektedir ${ }^{(14,16)}$. SENTRY programına göre ABD'deki kandidemilerin \%44'ü, Latin Amerika ülkelerindeki kandidemilerin \%59'u, Avrupa ve Kanada'daki kandidemilerin ise \%47'sinden ADC'ler sorumlu tutulmuştur ${ }^{(14)}$. Singhi ve ark. ${ }^{(19)}$ yalnızca PYBÜ ünitesini dâhil ettikleri çalışmada, ADC'ye bağlı kandidemi oran $\% 70.3$ ve en sik etken olarak C. tropicalis (\%48.4)'i bildirmişlerdir. Çalışmamızda PYBÜ'de C. parapsilosis'in etken olduğu kandidemi oranı \%33.4 olarak bulunmuştur. İspanya'da yapılan beş yıllık retrospektif bir çalışmada ise, ADC'lere bağlı kandidemi oranını (\%64.2), C. albicans'a bağlı kandidemi oranından (\%35.8) daha fazla bulmuşlardır. Ayrıca çalışmada, en sık kandidemi etkeni olarak C. parapsilosis (\%41.5) saptanmıştır ${ }^{(20)}$. Otağ ve ark.'nın ${ }^{(10)}$ yaptığ 1 çalışmada, kandidemilerin \%76.2'sinden ADC'ler sorumlu tutulmuştur ve kandidemi etkenleri arasında C. parapsilosis ilk sırada yer almıştır.

İmmünsüpresif hastalarda santral venöz kateter ve kalıcı kateterin uzun süre kullanılması C. parapsilosis enfeksiyon riskini arttırmaktadır. C. parapsilosis türlerinin yüksek glukoz ve lipid konsantrasyonları içeren besiyerlerinde üretildiklerinde biyofilm oluşturdukları gözlenmiştir. Bu durum parenteral beslenen hastaların kan dolaşımı enfeksiyonlarındaki yüksek prevalansla ilişkilendirilmiştir ${ }^{(21)}$. C. parapsilosis'in, plastik medikal aletlere karş1 seçiciliği, üriner kateter ve damar yolu kateterlerinde kolonize olması biyofilm oluşturma yeteneğine bağlı olduğu belirtilmiştir ${ }^{(22)}$. İspanya'da yapılan bir çalışmada ${ }^{(23)}, 72 C$. parapsilosis enfeksiyonlu hastada vasküler kateterizasyon (\%97), antibiyotik tedavisi (\%91), ameliyat geçmişi (\%46), immünsüpresif tedavi (\%38), malignite (\%27), transplantasyon (\%16), nötropeni (\%12), kolonizasyon (\%11) risk faktörleri olarak sıralanırken, Brezilya'da 2002-2003 yılları arasinda rapor edilen $64 C$. parapsilosis fungemili olguda primer risk faktörleri nötropeni, santral venöz kateter (SVK) kullanımı ve kanser kemoterapisi olduğu bildirilmiştir ${ }^{(24)}$. Çalışmamızda, TPN
(\%90.9), SVK varlığg (\%84.8) ve antibiyotik kullanımı (\%66.6) olarak tespit edilen risk faktörleri yaklaşık beş yıl önce hastanemizde yapılan başka bir çalışmanın bulgularıyla benzerdir ${ }^{(8)}$.

Hastane enfeksiyonları ve salgınlarında suşlar arasındaki klonal ilişkinin saptanması, bulaş kaynağının tespit edilmesi ve enfeksiyon kontrol önlemlerinin alınması açısından önem taşımaktadır ${ }^{(7,25)}$. Rep-PCR DiversiLab ${ }^{\circledR}$ sisteminin klinik örneklerde sık karşılaşılan Candida türlerinin (C.albicans, C.parapsilosis, $C$. glabrata, $C$. krusei ve $C$.tropicalis) suş seviyesinde ayrımında ve identifikasyonunda başarılı olduğu bildirilmiştir ${ }^{(13)}$.

Tayvan'da yapılan bir çalışmada, 53 C. albicans suşunun genotiplendirilmesinde, PFGE (Pulsedfield gel electrophoresis) yöntemiyle 38 farklı klon, rep-PCR yöntemiyle 31 farklı klon saptanmıştır. PFGE'nin ayrım gücünün yüksek olduğu belirlenmiştir ${ }^{(26)}$. Çin'de yapılan bir çalışmada, MLST (Multilokus Sekans Tiplendirme) ve repPCR yöntemleri karşılaştırılmış. Otuz dört C. glabrata suşunda 17 farklı klon tespit edilmiş, istatiksel analizler sonucunda rep-PCR' 1 ayrım gücü yüksek bulunmuştur ${ }^{(27)}$.

Çalışmamızda, 33 C. parapsilosis suşunun klonal ilişkileri rep-PCR DiversiLab ${ }^{\circledR}$ yöntemi ile araştırılmıştır. Rep-PCR analizi sonucunda, 33 C. parapsilosis suşundan 3 farklı klon (A-C) elde edilmiştir. A klonu 29 (\%87.8) C. parapsilosis suşunun kümelendiği en büyük klonu oluşturmuştur. A ana klonundaki ilk suş Ocak-2012 tarihinde REA' da son suş ise Haziran2013 tarihinde PYBÜ'de yatan hastadan izole edilmiştir. Bu klondaki suşların \%48.2'si REA, \%20.6's1 PYBÜ, \%17.2'si CYBÜ, \%13.7'si DYBÜ'de yatan hastalardan izole edilmiştir. Elde edilen veriler ile hastanemizdeki C. parapsilosis suşlarının büyük oranda klonal ilişkili dağılım göstererek A klonunda kümelendiği, A klonundaki suşların erişkin ve pediyatri yoğun bakım ünitelerinde yayıldığ 1 ve bu klondaki suşların çalışmanın yapıldığı 18 ay boyunca hastanedeki varlığını sürdürdüğü görülmüsştür. B klonunda kümelenen 3 suş 5 ay boyunca PYBÜ'de varlığını sürdürmüştür. Hastanede hastaların servisler arası transferleri, hastalar ve 
sağlık personeli aracılığıyla gerçekleşen çapraz bulaşlar sonucu suşların hastane içerisinde kolayca yayıldığ 1 ve uzun süre varlığını sürdürdügü yine ortaya konmuştur.

Çalışmamızın en önemli sınırlamaları, örnek sayısının az olması $(n=33)$, SVK örneklerinden izole edilen suşları kapsaması ve rep-PCR DiversiLab $^{\circledR}$ sistemi ile Candida türlerinin klonal ilişkisinin analizi ile ilgili verilerin az olmasıdır. Candida parapsilosis'in el florasında bulunması, biyofilm oluşturarak biyomedikal aletlere kolayca tutunması bu türü ADC türleri arasinda en fazla nozokomiyal enfeksiyon potansiyeli olan tür hâline getirmektedir. C. parapsilosis'in yoğun bakım ünitelerinde uzun süre yaygın olmasının temeli budur. Sonuç olarak, C. parapsilosis suşlarının hastane ortamındaki dağılımının klonal ilişki göstermesi, enfeksiyon kontrol programlarının önemini bir kez daha vurgulamış ve rep-PCR DiversiLab ${ }^{\circledR}$ sisteminin moleküler epidemiyolojik çalışmalarda başarıyla kullanılabileceği düşünülmüştür.

\section{KAYNAKLAR}

1. Soll DR. The ins and outs of DNA fingerprinting the infectious fungi. Clin Microbiol Rev 2000; 13:332-70.

http://dx.doi.org/10.1128/CMR.13.2.332-370.2000

2. Samaranayake LP, Fidel PL, Naglik JR, et al. Fungal infections associated with HIV infection. Oral Dis 2002; 8(Suppl 2):S151-60. http://dx.doi.org/10.1034/j.1601-0825.8.s2.6.x

3. Hagerty JA, Ortiz J, Reich D, Manzarbeitia C. Fungal infections in solid organ transplant patients. Surg Infect (Larchmt) 2003; 4:263-71. http://dx.doi.org/10.1089/109629603322419607

4. Bassetti M, Righi E, Costa A, et al. Epidemiological trends in nosocomial candidemia in intensive care. BMC Infect Dis 2006; 6:21.

http://dx.doi.org/10.1186/1471-2334-6-21

5. Colombo AL, Perfect J, DiNubile M, et al. Global distribution and outcomes for Candida species causing invasive candidiasis: results from an international randomized doubleblind study of caspofungin versus amphotericin B for the treatment of invasive candidiasis. Eur J Clin Microbiol 2003; 22:470-4. http://dx.doi.org/10.1007/s10096-003-0973-8

6. Yüksekkaya Ş, Fındık D, Arslan U. Yoğun bakım ünitesinde yatan hastaların idrarlarından izole edilen Candida türlerinin moleküler epidemiyolojisi ve antifungal duyarlılıkları. Mikrobiyol Bul 2011; 45:137-49.

7. Fridkin SK, Jarvis WR. Epidemiology of nosocomial fungal infections. Clin Microbiol Rev 1996; 9:499-511.

8. Horasan ES, Ersöz G, Göksu M, et al. Increase in Candida parapsilosis fungemia in critical care units: a 6-years study. Mycopathologia 2010; 170:263-8. http://dx.doi.org/10.1007/s11046-010-9322-5

9. Ergüt Sezer B, Arman D. Yoğun bakım ünitesinde gelişen fungal enfeksiyonlar. Yoğun Bakım Dergisi 2010; 9:121-8.

10. Otă F, Aslan G, Şen S, Özturhan H, Emekdaş G. 20032005 süresinde klinik örneklerden izole edilen maya türlerinin değerlendirilmesi. Infeks Derg 2005; 19:435-43.

11. Gülbudak H, Oktay E, Direkel Ş, Elçi K, Emekdaş G, Otağ F. Bir üniversite hastanesinde mayaların 9 yıllık profili. I. Ulusal Mikoloji Günleri Simpozyum Kitabı, Erzurum: Türkiye, 2014; 19.

12. Neppelenbroek KH, Seô RS, Urban VM, et al. Identification of Candida species in the clinical laboratory: a review of conventional, commercial, and molecular techniques. Oral Dis 2014; 20:329-44. http://dx.doi.org/10.1111/odi.12123

13. Wise MG, Healy M, Reece $K$, et al. Species identification and strain differentiation of clinical Candida isolates using the DiversiLab system of automated repetitive sequence-based PCR. J Med Microbiol 2007; 56:778-87. http://dx.doi.org/10.1099/jmm.0.47106-0

14. Pfaller MA, Castanheira M, Messer AS, Moet GJ, Jones RN. Variation in Candida spp. distribution and antifungal resistance rates among bloodstream infection isolates by patient age: report from the SENTRY Antimicrobial Surveillance Program (2008-2009). Diagn Microbiol Infect Dis 2010; 68:278-83. http://dx.doi.org/10.1016/j.diagmicrobio.2010.06.015

15. Erdem F, Tuncer Ertem G, Oral B, Karakoç E, Demiröz AP, Tülek N. Candida türlerine bağlı nozokomiyal enfeksiyonların epidemiyolojik ve mikrobiyolojik açıdan değerlendirilmesi. Mikrobiyol Bul 2012; 46:637-48.

16. Knoke M, Schulz K, Bernhardt H. Dynamics of Candida isolations from humans from 1992-1995 in Greifswald, Germany. Mycoses 1997; 40:105-10. http://dx.doi.org/10.1111/j.1439-0507.1997.tb00197.x

17. Da Silva EH, Ruiz Lda S, Matsumoto FE, et al. Candiduria in a public hospital of São Paulo (1999-2004): characteristics of the yeast isolates. Rev Inst Med Trop Sao Paulo 2007; 49:349-53. http://dx.doi.org/10.1590/S0036-46652007000600003

18. Jain N, Kohli R, Cook E, Gialanella P, Chang T, Fries BC. Biofilm formation by and antifungal susceptibility of Candida isolates from urine. Appl Environ Microbiol 2007; 73:1697-703. http://dx.doi.org/10.1128/AEM.02439-06

19. Singhi SC, Reddy TC, Chakrabarti A. Candidemia in a pediatric intensive care unit. Pediatr Crit Care Med 2004; 5:369-74. http://dx.doi.org/10.1097/01.PCC.0000123550.68708.20

20. Durân MT, Velasco D, Canle D, Moure R, Villanueva R. Antifungal susceptibility of Candida spp. isolates from blood cultures in a five-year period (1997-2001). Enferm Infect Microbiol Clin 2003; 21:488-92.

21. Nosek J, Holesova Z, Kosa P, Gacser A, Tomaska L. Biology and genetics of the pathogenic yeast Candida parapsilosis. Curr Genet 2009; 55:497-509. http://dx.doi.org/10.1007/s00294-009-0268-4

22. Trofa D, Gâcser A, Nosanchuk JD. Candida parapsilosis, an emerging fungal pathogen. Clin Microbiol Rev 2008; 21:606-25. http://dx.doi.org/10.1128/CMR.00013-08

23. Almirante B, Rodríguez D, Cuenca-Estrella $M$, et al. Epidemiology, risk factors, and prognosis of Candida parapsilosis bloodstream infections case-control population-based surveillance study of patients in Barcelona, Spain, from 2002 to 2003. J Clin Microbiol 2006; 44:1681-5. http://dx.doi.org/10.1128/JCM.44.5.1681-1685.2006

24. Brito LR, Guimãraes T, Nucci M, et al. Clinical and microbiological aspects of candidemia due to Candida parapsilosis in Brazilian tertiary care hospitals. Med Mycol 2006; 44:261-6. http://dx.doi.org/10.1080/13693780500421476

25. Gülay Z, Ergon C, Özkütük A, Yücesoy M, Biçmen M. Anestezi yoğun bakım ünitesi hastalarından izole edilen Candida albicans suşlarının antifungal ajanlara duyarlılığı ve molekuler epidemiyolojik izlemi. Mikrobiyol Bul 2002; 36:309-16.

26. Chen KW, Lo HJ, Lin YH, Li SY. Comparison of four molecular typing methods to assess genetic relatedness of Candida albicans clinical isolates in Taiwan. J Med Microbiol 2005; 54:249-58. http://dx.doi.org/10.1099/jmm.0.45829-0

27. Zhang W, Zheng B, Ying $\mathbf{C}$, Wang $\mathbf{Y}$, Zhang $\mathbf{H}$, Yang J. Application of rep-PCR in genotyping of Candida glabrata. $J$ Zhang Jiao Univ Med Scien 2012; 32:886. 